\title{
Study on Operating Characteristics of PV Power System Based on PV Power Station Integration Standards
}

\author{
Feng Zheng ${ }^{\text {a }}$, Changhong Deng, Hui Liu, Zhigang Zhang and Qijun Yi \\ School of Wuhan University, Hubei 430072, China \\ azhengfeng831209@163.com
}

Keywords: integration technology standard, control strategy, operation states.

\begin{abstract}
Based on the voltage-current characteristic of the photovoltaic (PV) cell and PV's integration technology standards, the more realistic imitational modeling of PV system for engineering application is presented. Through the operation standards of PV system and control of power electronics, the PV power system's actual operation characteristic can be obtained. In this paper, the modeling of the PV can be created by using MATLAB/SIMULINK, and the control strategy of inverter can be made through the PV's integration standards. According to the different operation states of PV system in the simulation environment, the research on various fault condition of power system with PV provides the theoretical basis for the grid-connected PV system.
\end{abstract}

\section{Introduction}

In this paper, through the former standards being integrated by the system model of grid-connected PV system based on the behavioral model of the PV cells, a PV power system utility model is presented. Using the control strategies to realize the PV power system's performance is considered in the various fault condition. Through the MATLAB/SIMULINK, the operation results verify the performance of the control strategies and provide the theoretical basis for grid-connected .PV power system.

\section{PV simulation model}

\subsection{PV cells behavior mode}

In this paper, a behavioural model [1][2] suitable for engineering practice is adopted. Manufacturers provide standard test conditions (T:2980F, S:1000 W/m²), and then critical parameters such as short-circuit current Isc, open-circuit voltage Uoc, output current of maximum power point Im and output voltage of maximum power point Um are afforded. According to the features of PV semiconductor voltage and current, the relationship of them can be written as:

$$
\left\{\begin{array}{l}
I=N I_{S C}\left[1-C_{1}\left(e^{U /\left(\mathbb{M C}_{2} U_{o c}\right)}-1\right)\right] \\
C_{1}=\left(1-I_{\mathrm{m}} / I_{S C}\right) e^{-U_{m} /\left(C_{2} U_{o c}\right)} \\
C_{2}=\left(U_{m} / U_{o c}-1\right)\left[\ln \left(1-I_{\mathrm{m}} / I_{S C}\right)\right]^{-1}
\end{array}\right.
$$

Where

$\mathrm{N} / \mathrm{M}=$ the number of series/ parallel

Based on the environment change the correction parameters can be expressed as:

$$
\left\{\begin{array}{l}
\Delta I=\frac{S}{S_{\text {ref }}}\left[1+a\left(t-t_{\text {ref }}\right)\right] \\
\Delta U=\left[1-c * \frac{\left(t-t_{\text {ref }}\right)}{t_{\text {ref }}}\right] \ln \left[e+b \frac{\left(S-S_{\text {ref }}\right)}{S_{\text {ref }}}\right]
\end{array}\right.
$$

Where a and c are the temperature compensation coefficients. And b is the light intensity compensation coefficient. The compensation coefficients can be utilized to modify the critical parameters shown as: 


$$
\left\{\begin{array}{l}
I_{s c}^{\prime}=I_{s c} * \Delta I \\
U_{s c}^{\prime}=U_{s c} * \Delta U \\
I_{m}^{\prime}=I_{m} * \Delta I \\
U_{m}^{\prime}=U_{m} * \Delta U
\end{array}\right.
$$

\subsection{Maximum Power Point Tracking (MPPT) control of photovoltaic cell}

Fig. 1 shows the flowchart of MPPT algorithm. When the deviation between the operating voltage $\mathrm{U}_{\mathrm{pv}}$ and $\mathrm{U}_{\mathrm{m}}$ is bigger than the set value $\Delta \mathrm{U}_{\text {ref }}$, the MPPT $\mathrm{D}_{\text {ref }}$ will be set as $\mathrm{D}_{\mathrm{m}}$. When the operating point is close to $\mathrm{P}_{\mathrm{m}}$ and the variations of voltage and current also approach to 0 , using the IC method to regulate output duty cycle $\mathrm{D}_{\text {ref }}$ of controller.

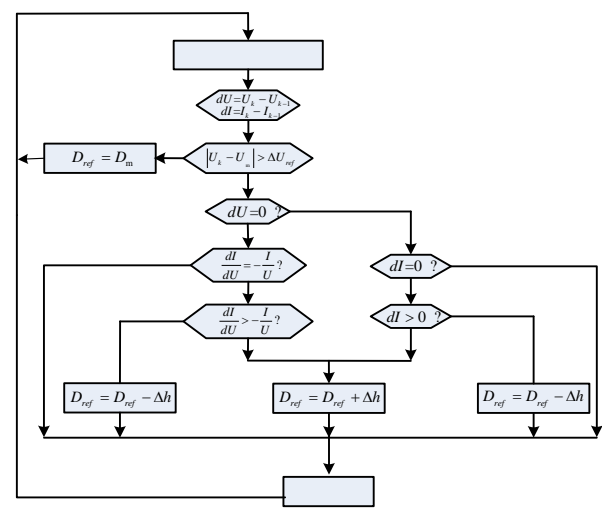

Fig.1 Flowchart of the Modified MPPT Algorithm

In grid-connected state, the P-Q control[3][4][5] is adopted for the PV power system and the power factor is set 0 . The P-Q control includes voltage outer loop and current inner loop controllers. The outer loop controller's references $\left(\mathrm{U}_{\mathrm{dc}}, \mathrm{U}_{\mathrm{ref}}\right)$ are determined by the system parameters, and the loop controller's current references can be calculated as ( $\mathrm{d}-\mathrm{q}$ axis decoupling is used):

$$
\left\{\begin{array}{l}
i_{\text {dref }}=\left(U_{d c}-U_{\text {ref }}\right) P I \\
i_{\text {qref }}=0
\end{array}\right.
$$

Accordingly, the P-Q control's output voltage signals $\left(\mathrm{u}_{\mathrm{d}}, \mathrm{u}_{\mathrm{q}}\right)$ used for triggering the master DG can be expressed as:

$$
\left\{\begin{array}{l}
u_{d}=\left(K_{p}+\frac{K_{i}}{S}\right)\left(i_{\text {Ldref }}-i_{L d}\right)-\omega L_{f} i_{L q}+u_{g d} \\
u_{q}=\left(K_{p}+\frac{K_{i}}{S}\right)\left(i_{\text {Lqref }}-i_{L q}\right)+\omega L_{f} i_{L d}+u_{g q}
\end{array}\right.
$$

The P-Q control block and schematic diagrams of the PV grid-connected system can be shown in Fig. 2.

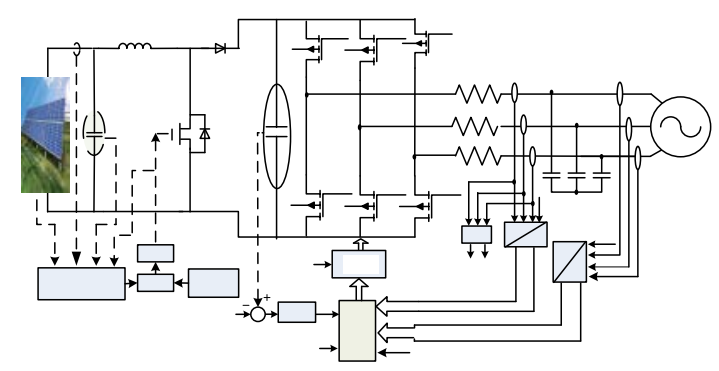

Fig.2 Grid-connection control of PV grid-connected system

\section{The PV integration standards of PV power system[1]}

\subsection{The demand of abnormal voltage and current response}

According to the scale of the PV power stations, the requirements of PV grid-connected voltage are different. The fig. 3 shows the assessment scope of the grid-side's voltage sag. The PV power stations can maintain 1 minute to run when the current under $120 \% \mathrm{I}_{\mathrm{N}}\left(\mathrm{I}_{\mathrm{N}}\right.$, current rating). If the current is 
between $120 \% \mathrm{I}_{\mathrm{N}}$ and $150 \% \mathrm{I}_{\mathrm{N}}$, The PV power stations can keep 10 s to operate. When the fault occurs, the current must below $150 \% \mathrm{I}_{\mathrm{N}}$.

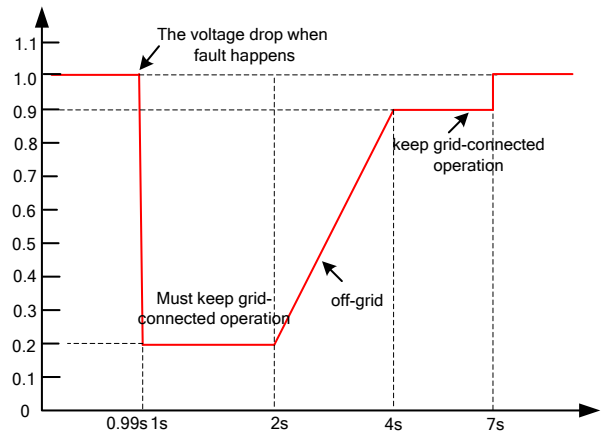

Fig.3 Low voltage ride through capability of large and Medium-sized on-grid PV power station

\section{Simulation Study}

\subsection{The simulation analyses of PV cell}

Fig.4 presents the output characteristics of the PV array in the different environmental conditions. From the simulation results, the model meets the simulation needs.

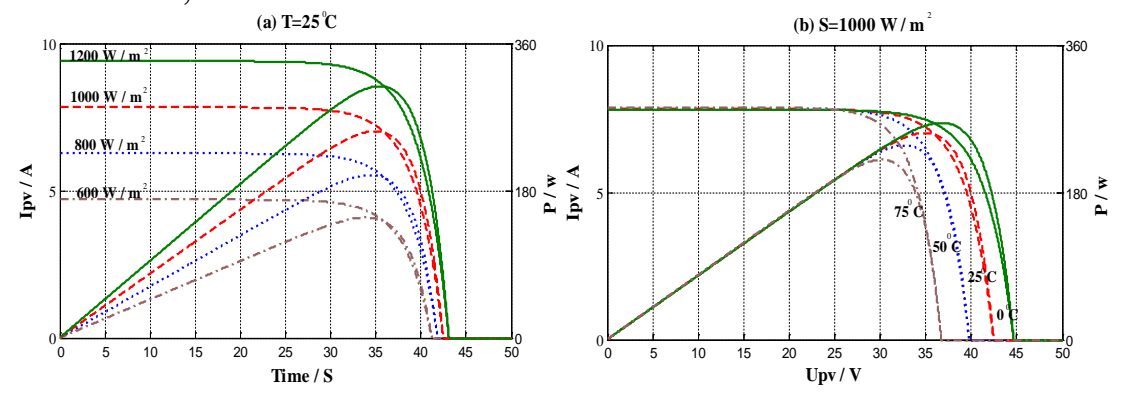

Fig.4 Output characteristics of the built PV array model (a) P-IPV (2) P-Vpv

\subsection{The simulation analyses of PV cell}

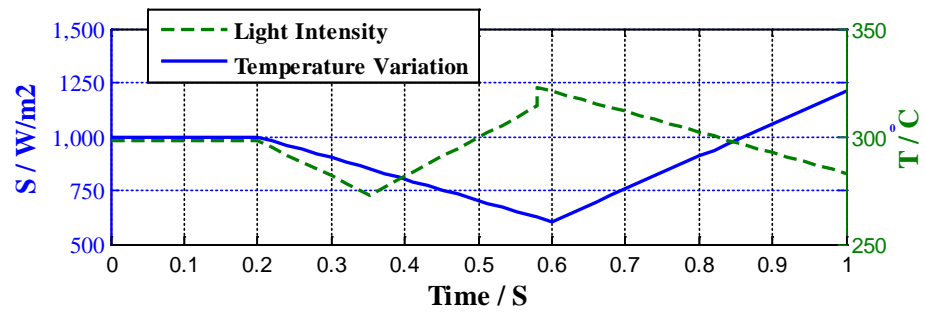

Fig.5 Variation curves of irradiance and temperature
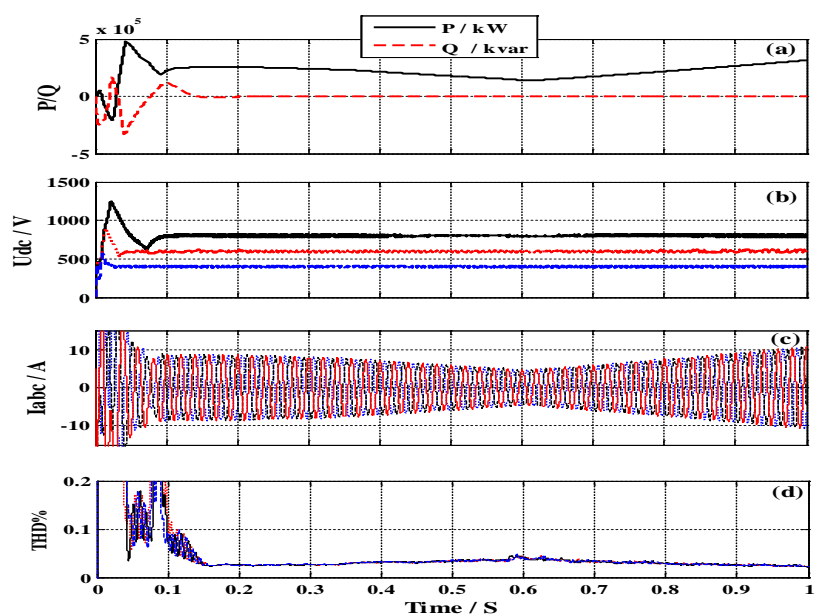

Fig.6 Output characteristics of PV power System 
Fig. 5 shows the environmental conditions. Based on the former environmental conditions Fig.6 demonstrates output characteristics of PV power System. From fig.6 (a) and (c), the active, reactive powers and output current of inverter all follow the environmental change, and output direct voltage can respectively control at the set value such as $400 \mathrm{~V}, 600 \mathrm{~V}$ and $800 \mathrm{~V}$. The THD of the inverter's current always under the standard.

\subsection{The transient analysis of PV power system based on the PV integration standards}
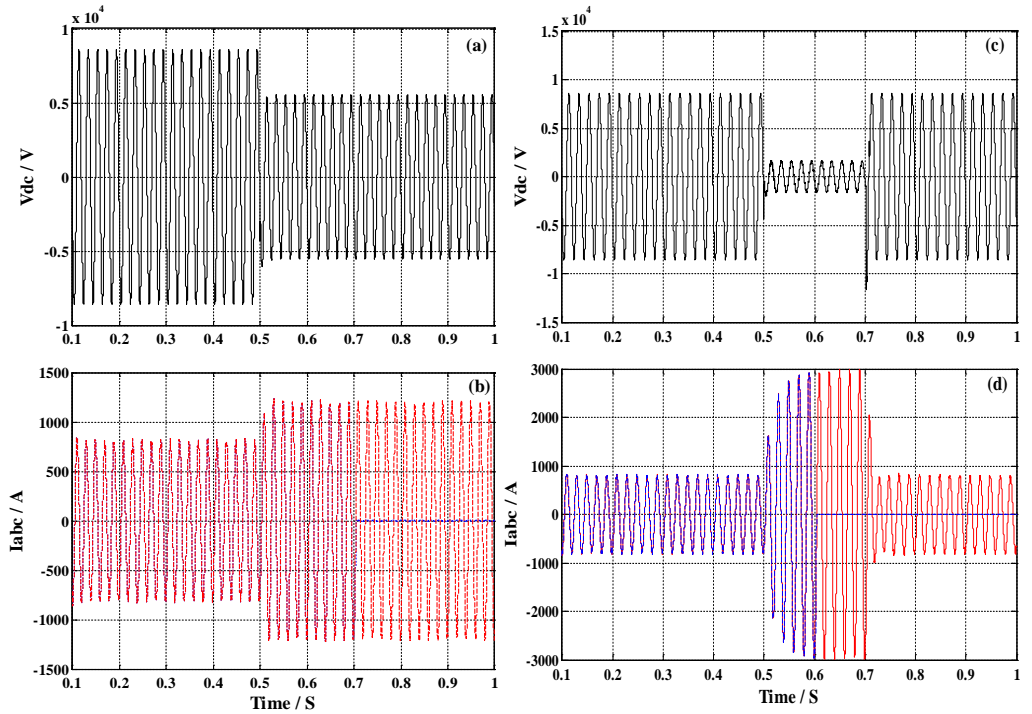

Fig.7 Output current characteristics under the different voltage's standers

Fig.7 (a) and (c) respectively demonstrate the changes in voltage. In order to expressed the results in a better way, the maximum opening times of $\mathrm{U}<50 \% \mathrm{U}_{\mathrm{N}}$ and $50 \% \mathrm{U}_{\mathrm{N}}<\mathrm{U}<85 \% \mathrm{U}_{\mathrm{N}}$ are respectively set as $0.2 \mathrm{~s}$ and $0.1 \mathrm{~s}$. From fig.7 (b) and (d), the changes of output current of inverter corresponding to the fig. (a) And (c) are shown. Fig.7 (b) / (d) shows that the current is cut off at the $0.2 \mathrm{~s} / 0.1 \mathrm{~s}$ when the voltage of the $50 \% \mathrm{U}_{\mathrm{N}}<\mathrm{U}<85 \%$ / $\mathrm{U}<50 \% \mathrm{U}_{\mathrm{N}}$.

\section{Conclusions}

In this paper, related technical discussions of the PV cells model is carried out. And according to PV integration standards the control strategy of the inverter is presented. As a result, the goal of control requirement can be achieved by using PV integration standards. Through this way, it will provide theoretical basis for engineering practice.

\section{References}

[1] Jiao Yang, Song Qiang, Liu Wenhua. Control strategy of grid-connected photovoltaic generation system based on modified MPPT method. Electric Power Automation Equipment, 30(12), 2010, pp. 92-96.

[2] Yang Yongheng, Zhou Keliang. Photovoltaic Cell Modeling and MPPT Control Strategies. Transaction of China Electro technical Society, 26(1), 2011, pp. 229-234.

[3] KONG Ling-guo, CAI Guo-wei. Research on control method of inverters for large-scale grid-connected photovoltaic power system. Power System Protection and Control, 41(22), 2013, pp. 57-63.

[4] LI Zebin, LUO An, TIAN Yuan, et al. Inner Current Loop Control Method for Photovoltaic Grid-Connected Inverter With LCL Filter. Electric Power Automation Equipment, 38(10), 2014, pp. 2772-2778.

[5] Tang Ci. Four design methods for proportional-integral controller of grid-connected inverter with LCL output filter. Power System Technology, 37(11), 2013, pp. 3268-3275. 